\title{
KEMAMPUAN MATEMATIKA ANAK USIA 5-6 TAHUN DI KOBER AL-HIDAYAH KECAMATAN CIKONENG KABUPATEN CIAMIS
}

\author{
Sumardi $^{1}$, Lutfi Nur ${ }^{2}$, Hilma Halimatus Sa'diyyah ${ }^{3}$ \\ ${ }^{1}$ Program Studi PGPAUD UPI Kampus Tasikmalaya \\ ${ }^{2}$ Program Studi PGPAUD UPI Kampus Tasikmalaya \\ ${ }^{3}$ Program Studi PGPAUD UPI Kampus Tasikmalaya \\ Email: sumardipgpaud@gmail.com
}

(Received: Mei 2017; Accepted: Mei 2017; Published: Juni 2017)

\begin{abstract}
This research is motivated by the theory of mathematics learning in early childhood which has two main areas of numbers and geometry, so the researcher focuses this research on two fields. The research is a descriptive study on the mathematical ability of children aged 5-6 years in Kober AlHidayah Cikoneng subdistrict Ciamis regency. The purpose of this study is to describe the level of mathematical ability such as describe the ability to recognize numbers in the cardinal and ordinal, and the ability to recognize the shape of 2 dimensional geometry and 3 dimensions. The approach of research method used is quantitative method with the aim to test the theory about variable Mathematical ability in children aged 5-6 years. The research method used is survey method. The stages of this research are: 1) conducting preliminary study and problem identification. 2) data collection phase. 3) data analysis as the answer to the problem. 4) conclusion. The sample used is a saturated sample of 17 children. Data collection tools are test and observation sheet. The result of this research that 1) the mathematics ability of children aged 5-6 years in Kober Al-Hidayah Cikoneng sub-district of Ciamis Regency included in the criteria develop as expected with percentage 74,26\% from total of all children, 2) ability to know cardinal number of child age 5-6 years in Kober Al-Hidayah Cikoneng subdistrict Ciamis regency has a percentage of $94.11 \%$ of the total of all children, and the ability to recognize ordinal numbers has a percentage of $69.11 \%$ of the total of all children, and 3) the ability to recognize 2 dimensional geometry Children aged 5-6 years in Kober Al-Hidayah Cikoneng subdistrict Ciamis regency has a percentage of $70.58 \%$ of the total of all children, while the ability of 3-dimensional geometry has a percentage of 57.35\% of the total of all children.
\end{abstract}

Keyword: mathematic, number, geometry.

\begin{abstract}
ABSTRAK
Penelitian ini dilatarbelakangi oleh adanya teori tentang pembelajaran matematika pada anak usia dini yang memiliki dua bidang utama yaitu angka dan geometri, sehingga peneliti memfokuskan penelitian ini pada dua bidang tersebut. Penelitian yang dilakukan merupakan penelitian deskriptif terhadap kemampuan matematika anak usia 5-6 tahun di Kober Al-Hidayah Kecamatan Cikoneng Kabupaten Ciamis. Tujuan dari penelitian ini yaitu untuk mendeskripsikan tingkat kemampuan matematika diantaranya mendeskripsikan kemampuan mengenal angka dalam kardinal dan ordinal, serta kemampuan mengenal bentuk geometri 2 dimensi dan 3 dimensi. Pendekatan metode penelitian yang digunakan adalah metode kuantitatif dengan tujuan untuk menguji teori tentang variabel kemampuan matematika pada anak usia 5-6 tahun. Metode penelitian yang digunakan adalah metode survey. Tahapan penelitian ini yaitu : 1) melakukan studi pendahuluan dan identifikasi masalah. 2) tahap pengumpulan data. 3) analisis data sebagai jawaban dari masalah. 4) kesimpulan. Sampel yang digunakan ialah sampel jenuh yang berjumlah 17 anak. Alat pengumpulan data berupa tes dan lembar observasi. Hasil dari penelitian ini bahwa 1) kemampuan matematika anak usia 5-6 tahun di Kober Al-Hidayah Kecamatan Cikoneng Kabupaten Ciamis termasuk dalam kriteria berkembang sesuai harapan dengan persentase $74,26 \%$ dari total seluruh anak, 2) kemampuan mengenal angka kardinal anak usia 5-6 tahun di Kober Al-Hidayah Kecamatan Cikoneng Kabupaten Ciamis memiliki persentase sebanyak 94,11\% dari total seluruh anak, dan pada kemampuan mengenal angka ordinal memiliki persentase sebanyak $69,11 \%$ dari total seluruh anak, dan 3) kemampuan mengenal geometri 2 dimensi anak usia 5-6 tahun di Kober Al-Hidayah Kecamatan Cikoneng Kabupaten Ciamis memiliki persentase sebanyak 70,58\% dari total seluruh anak, sedangkan pada kemampuan geometri 3 dimensi memiliki persentase sebanyak $57,35 \%$ dari total seluruh anak.
\end{abstract}

Kata Kunci: matematika, angka, geometri. 


\section{PENDAHULUAN}

Cross dkk. (2009, hlm. 21) menjelaskan bahwa matematika menyediakan sarana yang kuat untuk memahami dan menganalisis dunia. Matematis menggambarkan dan mewakili kuantitas, bentuk, ruang, dan pola yang membantu untuk mengatur wawasan dan ide-ide manusia tentang dunia dengan cara yang sistematis. Beberapa sistem matematika telah menjadi seperti bagian mendasar dari kehidupan sehari-hari.

Sriningsih (2009, hlm. 22) menyimpulkan bahwa

Hakikat matematika untuk anak usia dini merupakan sarana yang dapat digunakan untuk mengembangkan kemampuan berpikir, mendorong anak untuk mengembangkan berbagai potensi intelektual yang dimilikinya serta dapat dijadikan sebagai sarana untuk menumbukan berbagai sikap dan prilaku positif dalam rangsa meletakkan dasardasar kepribadian sedini mungkin seperti sikap kritis, ulet, mandiri, ilmiah dan rasional.

Pendidikan anak usia dini atau disingkat menjadi PAUD merupakan jenjang pendidikan anak dari usia 0-6 tahun, pada jenjang inilah anak diberi berbagai rangsangan untuk tumbuh kembang anak di usia emas sehingga memiliki kesiapan untuk memasuki jenjang pendidikan yang lebih tinggi. Menurut Permendikbud No. 137 Tahun 2014, lingkup perkembangan sesuai tingkat anak meliputi 6 aspek yaitu nilai agama dan moral; fisik motorik; kognitif; bahasa; sosial emosional; dan seni. Sriningsih (2009) mengemukakan bahwa dalam praktik pembelajaran matematika anak usia dini baik di jalur formal maupun informal mengembangkan 3 istilah yaitu: pengembangan kognitif, daya pikir dan pengembangan kemampuan matematika.

Konsep matematika dapat dibangun dari kegiatan yang anak lakukan sehari-hari. Anak akan terlebih dahulu mendengar dan mengucapkan konsep matematika yang diperoleh dari lingkungannya, kemudian seiring bertambah usia anak akan berkembang untuk memahami konsep matematika lebih mendalam. Dalam mempelajari konsep matematika, anak memerlukan kemampuan untuk berpikir abstrak yang disesuaikan dengan tingkat usianya. Oleh karena itu dalam mengajarkan konsep matematika hendaknya disesuaikan dengan tahapan perkembangan kognitif. Tahapan perkembangan kognitif menurut Piaget (Sriningsih, 2009) antara lain: sensorimotor usia 0-2tahun; praoperasional usia 2-7 tahun; operasional kongkrit usia 7-12 tahun; dan operasional formal usia 12 tahun ke atas.

Dari pemaparan diatas, penelitian ini mencoba untuk mengungkap pada anak dengan tahap kognitif praoperasional usia 4-7 tahun yang dibagi menjadi dua sub fase berpikir. Namun peneliti menyesuaikan dengan subjek penelitian yaitu anak kelompok usia 5-6 tahun yang berada pada fase berpikir secara intuitif. Menurut Sujiono (2012) dalam bukunya berjudul Konsep Dasar Pendidikan Anak Usia Dini menyatakan bahwa "berpikir secara intuitif (4-7 tahun) yaitu kemampuan untuk menciptakan sesuatu (menggambar atau menyusun balok), tetapi anak tidak mengetahui alasan pasti mengapa melakukan hal tersebut. Pada usia ini anak sudah dapat mengklasifikasi subjek sesuai dengan kelompoknya". Feldman (dalam Rohmah \& Waluyo 2014, hlm. 128) menjelaskan bahwa pada tahap praoperasional, anak berpikir simbolis, mental penalaran mulai muncul dan penggunaan konsepnya meningkat.

Cross dkk. (2009) menjelaskan bahwa, ".. mathematic for young children in two core areas: (1) number and (2) geometry". Matematika untuk anak usia dini memiliki dua bidang utama, yaitu jumlah dan geometri, sehingga peneliti memfokuskan 
pada penelitian ini pada dua bidang tersebut.

Dari hasil peninjauan Permendikbd No 137 Tahun 2014 tentang Standar Pencapaian Perrkembangan Anak pada aspek perkembangan kognitif dalam lingkp perkembangan berpikir logis dan berpikir simbolik bahwa anak usia 5-6 tahun mampu:

1. Mengenal perbedaan berdasarkan "lebih dari"; "kurang dari"; dan "paling/ ter"

2. Mengklasifikasikan benda berdasakan warna, bentuk dan ukuran (3 variasi)

3. Mengurutkan benda berdasarkan ukuran dari paling kecil ke paling besar atau sebaliknya

4. Menyebutkan lambang bilangan 1-10

5. Menggunakan lambang bilangan untuk menghitung

6. Mencocokkan bilangan dengan lambang bilangan

Kober Al-Hidayah merupakan lembaga nonformal di jenjang Pendidikan Anak Usia Dini yang memfasilitasi pembelajaran sesuai dengan kelompok usia anak. Dari hasil studi pendahuluan yang peneliti lakukan bahwa Kober Al-Hidayah di kelompok usia 5-6 tahun memiliki kemampuan kognitif yang sesuai dengan standar tingkat pencapaian perkembangan pada usianya, terutama perkembangan kemampuan matematika. Dari hasil observasi peneliti, pendidik atau guru di Kober Al-Hidayah tidak memiliki data dan laporan perkembangan anak yang khusus memaparkan kemampuan anak, sehingga guru dan orangtua tidak mengetahui data lengkap yang dapat mendukung perkembangan tentang indikator kemampuan matematika yang belum dicapai, akan dicapai dan sudah dicapai oleh anak.

Rumusan masalah berikut merupakan masalah yang dijadikan fokus dari penelitian. Secara umum rumusan masalahnya adalah "Bagaimana kemampuan matematika anak pada usia 5-6 tahun di Kober Al-Hidayah Ciamis?:
Secara khusus, rumusan masalahnya adalah sebagai berikut:

1. Bagaimana kemampuan mengenal angka dalam kardinal dan ordinal anak usia 5-6 tahun di Kober Al-Hidayah Ciamis?

2. Bagaimana kemampuan mengenal bentuk geometri 2 dimensi dan 3 dimensi anak usia 5-6 tahun di Kober Al-Hidayah Ciamis?

Tujuan penelitian ini secara umum adalah untuk mendeskripsikan kemampuan matematika anak usia 5-6 tahun di Kober Al-Hidayah Ciamis.

Secara khusus tujuan penelitian ini adalah:

1. Untuk mendeskripsikan kemampuan mengenal angka dalam kardinal dan ordinal pada anak usia 5-6 tahun di Kober Al-Hidayah Ciamis.

2. Untuk mendeskripsikan kemampuan mengenal bentuk geometri 2 diemnsi dan 3 dimensi anak usia 5-6 tahun di Kober Al-Hidayah Ciamis.

\section{TINJAUAN PUSTAKA}

Cross dkk. (2009) menjelaskan bahwa matematika menyediakan sarana yang kuat untuk memahami dan menganalisis dunia. Matematis menggambarkan dan mewakili kuantitas, bentuk, ruang, dan pola yang membantu untuk mengatur wawasan dan ide-ide manusia tentang dunia dengan cara yang sistematis. Beberapa sistem matematika telah menjadi seperti bagian mendasar dari kehidupan sehari-hari.

Matematika merupakan salah satu jenis pengetahuan yang dibutuhkan manusia dalam menjalankan kehidupannya seharihari. Mengenalkan konsep matematika dapat dilakukan melalui kegiatan seharihari. Dalam buku Konsep Matematika untuk Anak Usia Dini yang diterbitkan oleh Dirjen Pendidikan Anak Usia Dini Nonformal dan Informal Kemendiknas (2011) dipaparkan bahwa untuk mengenalkan konsep logika matematika 
pada anak usia 5-6 tahun dapat dilakukan melalui kegiatan sederhana dan konkrit.

Cross dkk. (2009) menjelaskan bahwa, ".. mathematic for young children in two core areas: (1) number and (2) geometry". Matematika untuk anak usia dini memiliki dua bidang utama, yaitu jumlah dan geometri, sehingga peneliti memfokuskan pada penelitian ini pada dua bidang tersebut.

\subsection{Angka (number)}

Angka atau nomor merupakan cara mendasar untuk menggambarkan dunia, sehingga jumlahnya abstraksi karena berlaku untuk berbagai situasi nyata. Angka atau nomor seringkali digunakan untuk kegiatan sehari-hari, misalnya untuk

mengetahui jumlah apel di pohon, jumlah rumah di suatu kota, atau jumlah bola di tempat bermain anak.

Clements dan Sarama (2009) mengungkapkan bahwa pada Pendidikan Anak Usia Dini (PAUD) terdapat pola-pola dalam menghitung yang dapat membantu anak mengembangkan jumlah abstrak dan strategi aritmatika, diantaranya:

a. Pola Temporal, yaituketika anak berpikir abstrak "saya tahu bahwadarikoleksibuahapeltersebutadale bihdaritiga".

b. PolaSpasial,

yaituanakmenghitungdengankonsepmen ggunakandadu, domino atausimbollainnya.

c. PolaKinestetik, yaituanak menghitung dengan menggunakan pola jari dan berirama.

\section{Menurut Epstein}

mengungkapkan bahwa "Counting involves learning the squence of number words, identifying the quantity of item in a collection (knowing that the last counting word tells "how many"), and recognizing counting patterns...", berarti bahwa penghitungan angka melibatkan urutan nomor dan kuantitas dalam koleksi (kardinal dan ordinal).

Menurut Clements (1984) (dalam Clements dan Sarama, 2009, hlm. 20) mengungkapkan bahwa anak harus memahami 2 logis (kardinal dan ordinal) agar memahami nomor dengan baik. Kedua ideologis tersebut dapat membantu anakanak untuk memahami ide-ide logis. Artinya, penghitungan dapat membantu anak dalam mengembangkan pengetahuan klasifikasi dan seriation.

Clemson dan Clemson (1994) mengungkapkan bahwa dalam penghitungan menggunakan angka kardinal dan nomor juga digunakan untuk menunjukkan urutan kejadian atau objek, yaitu deskriptor ordinal.

Berdasarkan teori diatas, peneliti membatasi fokus penelitian pada dua ranah, yaitu:

2.1.1 Angka Kuantitas (number quantity or cardinal)

Angka kardinal menjelaskan tentang "berapa banyak", dengan kata lain bahwa angka sebagai informasi tentang berapa banyak jumlah yang ada pada suatu kelompok atau tempat. Pada awalnya beberapa mainan beruang dalam keranjang hanya terlihat seperti "beberapa beruang", tapi jika menggunakan konsep kardinal maka informasi tentang jumlah mainan beruang dalam keranjang dapat lebih tepat. Angka kardinal berarti pemaknaan dari sebuah angka. Ketika anak memahami bahwa angka dua (2) itu berarti dua buah apel, dua ekor ayam atau dua orang teman maka ia sudah memahami angka kardinal.

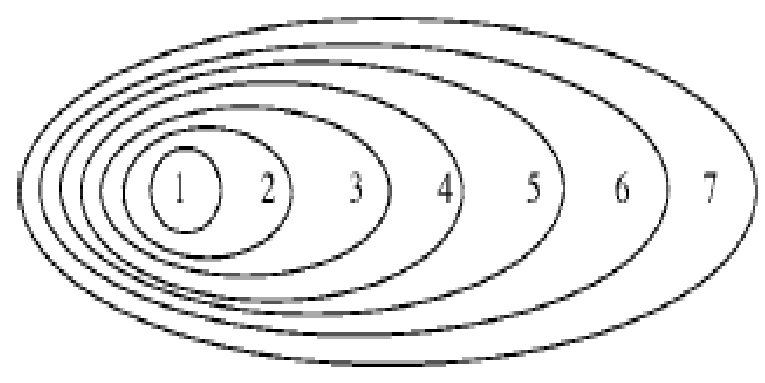


Gambar 1 Klasifikasi Hierarkis (kardinal atau "berapa banyak" benda)

\subsubsection{Angka Urutan (number list or ordinal)}

Angka urutan menjelaskan tentang nomor urutan yang dimulai dengan angka 1 dan dilanjutkan dengan angka 2, 3, 4, 5, 6, $7, \ldots$ dst. Urutan dari angka tersebut tidak akan tertukar posisinya dan setiap angka dari urutan tidak akan terulang di urutan lainnya atau dalam daftar penghitungan nomor hanya muncul sekali. Angka urutan atau ordinal memiliki pengaruh besar dalam menghitung angka kuantitas, karena dengan menalar urutan angka dengan baik dan benar maka dapat menentukan jumlah subjek dalam satu koleksi. Pada perhitungan jumlah subjek dalam satu koleksi, angka atau nomor yang disebutkan pada akhir subjek memiliki status khusus yaitu menentukan jumlah subjek dalam satu koleksi.

Jean Piaget juga menjadikan angka urutan atau ordinal sebagai logika yang mendasari dan diperlukan anak tentang jumlah sebelum menghitung makna yang disebut dengan sequencing, yaitu anak-anak harus benar menghasilkan jumlah kata (verbal counting) dalam urutan dan menghitung urutan benda mereka sehingga mereka menghitung setiap subjek dengan tepat.

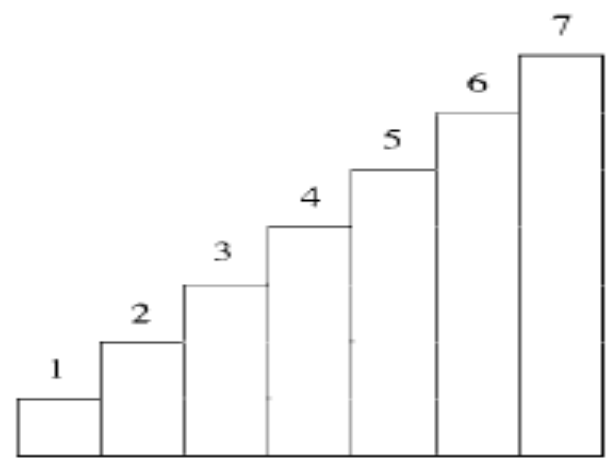

Gambar 2 Squencing (ordinal)

\subsection{Geometri}

Geometri merupakan bidang matematika yang menjelaskan, mewakili dan memahami dunia, karena seluruh aspek yang ada di dunia tidak terlepas dari sifatsifat geometri seperti bentuk dan ruang.

Geometri berada sangat dekat dengan dunia anak. anak dapat mengenali konsep geometri melalui gambar maupun bendabenda disekitarnya seperti piring, bantal, gelas dan sebagainya. Menurut Seefelt dan Galper (2008) mengungkapkan bahwa, “ the more children work with geometric concepts, the more they can learn to explore spatial relations and experience mathematics" yang berarti bahwa semakin banyak anak belajar tentang geometri, maka mereka semakin dapat belajar untuk mengeksplorasi hubungan spasial dan pengalaman matematika.

Menurut Seefelt dan Galper (2008) mengungkapkan bahwa, "the study of shapes should focus on the attributes and properties of both two and three dimensional shapes" yang berarti bahwa pembelajaran geometri harus terfokus pada 2-D dan 3-D beserta aspek dan sifatsifatnya.

Berdasarkan teori diatas, peneliti membatasi fokus penelitian pada dua ranah, yaitu:

\subsubsection{2-D}

Dua dimensi merupakan suatu benda yang memiliki sisi panjang dan lebar, sehingga tidak mempunyai ruang karena tidak mempunyai unsur ketebalan. Ciri-ciri 2-D tersebut biasanya terdapat pada karya seni rupa.

Pada Pendidikan Anak Usia Dini, 2-D merupakan karya seni rupa yang sering ditemui dalam kegiatan pembelajarannya. Anak melakukan kegiatan menggunting, menempel dan menggambar diatas kertas yang hasilnya dapat menjadi sebuah karya seni rupa 2-D. Dalam bidang geometri, bentuk segitiga, persegi panjang dan lingkaran merupakan contoh dari bentuk 2D. 

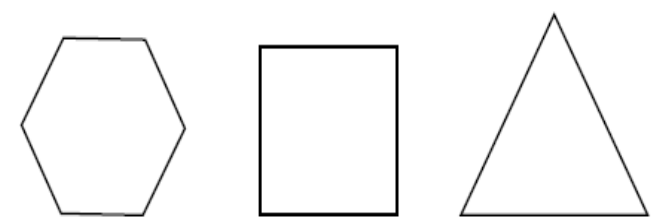

Gambar 3 Contoh Bentuk 2D

\subsubsection{3-D}

Menurut Wikipedia, 3 dimensi atau biasa disingkat menjadi 3-D merupakan bentk dari benda yang panjang, lebar dan tinggi. Dalam mengenalkan konsep 3-D pada Pendidikan Anak Usia Dini (PAUD) seringkali menggunakan permainan balok konstruksi, karena permainan tersebut telah lama menjadi permainan pokok yang berkualitas tinggi untuk mengembangkan aspek kognitif anak. Permainan balok konstruksi dapat mendukung pembelajaran tentang bentuk kemampuan komposisi bentuk dan membantu mengembangkan penalaran, dan dapat membantu anak untuk mengembangkan konsep matematika dasar dan keterampilan spasial.

Permainan balok kontruksi merupakan salah satu permainan yang menarik bagi anak usia dini, karena selalu disediakan dalam warna dan bentuk yang beragam. Menurut Clements dan Sarama (2004) mengungkapkan bahwa, "very young children can learn rich concepts about shape, if provided with varied examples and non-examples, discussions about shapes and their characteristics, and interesting tasks" yang berarti bahwa mengajarkan konsep geometri pada anak usia dini harus dengan menggunakan hal yang menarik.

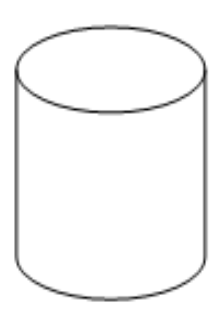

Gambar 4 Contoh Bentuk 3D

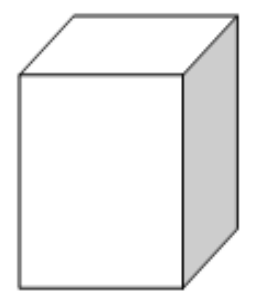

METODE 
Peneliti melakukan penilaian dengan menggunakan lembar observasi dari hasil test yang sudah dilakukan oleh anak kelompok usia 5-6 tahun di Kober AlHidayah.

Hasil pengumpulan data yang diperoleh melalui pemberian tes kemudian peneliti analisis dengan menggunakan statistika deskriptif dan dibuat persentasenya.

\subsection{Teknik Analisis Data}

Peneliti menggunakan statistika deskriptif yaitu mengolah data dengan distribusi freakuensi. Mulyana dan Nur (2015, hlm. 58) mengemukakan bahwa distribusi frekuensi dapat dibuat dengan mengikuti pedoman berikut:

3.2.1 Mengurutkan data dari yang terkecil ke yang terbesar.

3.2.2 Menentukan jangkauan (range) dari data. Jangkauan $=$ data terbesar - data terkecil.

3.2.3 Menentukan banyaknya kelas (k). Banyaknya kelas ditentukan dengan rumus Sturgess

3.2.4 Menentukan panjang interval kelas. Panjang interval kelas $(i)=$ jangkauan $(R)$ banyaknya kelas $(k)$

3.2.5 Menentukan batas bawah kelas pertama.

3.2.6 Membuat tabel frekuensi.

3.2.7 Menentukan rata-rata.

3.2.8 Menentukan modus.

3.2.9 Menentukan median.

\section{HASIL DAN PEMBAHASAN}

\subsection{Kemampuan Matematika}

Dalam buku Konsep Matematika untuk Anak Usia Dini yang diterbitkan oleh Dirjen Pendidikan Anak Usia Dini Nonformal dan Informal Kemendiknas (2011, hlm. 18) dipaparkan bahwa untuk mengenalkan konsep logika matematika pada anak usia 5-6 tahun dapat dilakukan melalui kegiatan sederhana dan konkrit yaitu meminta anak menghitung jumlah cangkir yang diperlukan untuk mengisi botol sampai penuh, sehingga dengan demikian anak dapat memahami angka secara kardinal dan ordinal. Pada pengembangan geometri anak juga dapat dikenalkan dengan penataan benda-benda bentuk geometri di lingkungan sekitar, mengenalkan tentang ciri-ciri dari setiap bentuk geometri, dan berkreasi dengan bermain balok konstruksi.

Hoerr dkk.(2011, hlm. 139) menjelaskan bahwa guru perlu memasukkan konsep kemampuan matematika ke dalam seluruh aspek perkembangan anak. Kemampuanmatematikasangatberpengaruh terhadap proses berpikir anak pada seluruh aspek perkembangannya. Bagi anak yang memiliki kecenderungan pada kemampuan matematika akan lebih memilih untuk sering berkontribusi pada pemecahan masalah dan memanfaatkan keterampilan yang dianggap logis. Hasil dari observasi peneliti bahwa setiap tema pembelajaran guru selalu mengimplementasikan pembelajaran matematika yaitu berhitung. Selain itu kemampuan anak dalammengenalaspekangka juga dipengaruhiolehlingkungankeluargadengan stimulus yang berbeda-bedapadamasingmasinganak.

Berdasarkan hasil tes dan observasi di Kober Al-Hidayah Kecamatan Cikoneng Kabupaten Ciamis, diperoleh data bahwa kemampuan matematika anak usia 5-6 tahun termasuk dalam kriteria berkembang sesuai harapan. Hasil tersebut ditunjukkan dengan persentase $74,26 \%$ dari total keseluruhan anak. Hal tersebut dapat dipengaruhi oleh beberapa faktor, diantaranya stimulasi yang diberikan pada anak dalam pengembangan kemampuan matematika baik oleh keluarga maupun lingkungan sekolah.

Hasil tes yang diberikan pada 17 anak terdapat 7 anak berada pada kriteria berkembang sangat baik yaitu dengan persentase $41,18 \%$. Pada kriteria 
berkembang sesuai harapan terdapat 9 anak dengan persentase $52,94 \%$, pada kriteria mulai berkembang terdapat 1 anak dengan persentase $5,88 \%$, dan berdasarkan hasil tes tidak ada anak yang berada dalam kriteria belum berkembang. Sehingga berdasarkan hasil test dapat disimpulkan bahwa sebagian besar $(52,94 \%$ dari total keseluruhan) kemampuan matematika anak usia 5-6 tahun di Kober Al-Hidayah berada dalam kriteria berkembang sesuai harapan.

Untuk lebih jelasnya persentase kemampuan matematika anak usia 5-6 tahun di Kober Al-Hidayah Kecamatan Cikoneng Kabupaten Ciamis dapat dilihat dari gambar tersebut:

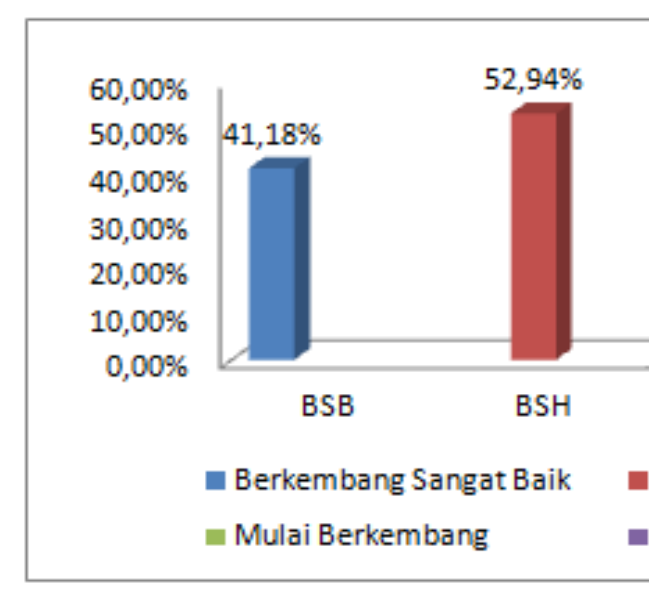

Gambar 5

Histogram Kriteria Penilaian Anak pada Kemampuan Matematika

\subsection{Kemampuan Aspek Angka}

Kemampuan mengenal angka kardinal anak usia 5-6 tahun di Kober Al-Hidayah Kecamatan Cikoneng Kabupaten Ciamis memiliki persentase sebanyak $94,11 \%$ dari total seluruh anak. Angka kardinal menjelaskan tentang "berapa banyak", dengan kata lain bahwa angka sebagai informasi tentang berapa banyak jumlah yang ada pada suatu kelompok atau tempat. Angka kardinal berarti pemaknaan dari sebuah angka. Ketika anak memahami bahwa angka dua (2) itu berarti dua buah apel, dua ekor ayam atau dua orang teman maka ia sudah memahami angka kardinal.
Tabel 1 Kemampuan Sub Aspek Angka Kardinal

\begin{tabular}{llcc}
\hline No. & \multicolumn{1}{c}{$\begin{array}{c}\text { Angka } \\
\text { Kardinal }\end{array}$} & $\begin{array}{c}\text { Jumlah } \\
\text { Anak }\end{array}$ & Persentase \\
\hline & $\begin{array}{l}\text { Mengetahui } \\
\text { jumlah item } \\
\text { (benda konkrit) } \\
\text { dalam koleksi. }\end{array}$ & 15 & $88,23 \%$ \\
2. $\begin{array}{l}\text { Mengetahui } \\
\text { jumlah item } \\
\text { dalam domino. }\end{array}$ & 15 & $88,23 \%$ \\
3. $\begin{array}{l}\text { Menghitung } \\
\text { dengan pola } \\
\text { jari. }\end{array}$ & 17 & $100 \%$ \\
\hline Menghitung \\
dengan pola \\
berirama.
\end{tabular}

Kemampuan mengenal angka ordinal pada anak kelompok usia 5-6 tahun di Kober Al-Hidayah Kecamatan Cikoneng Kabupaten Ciamis memiliki persentase sebanyak $69,11 \%$ dari total seluruh anak. Hal tersebut disebabkan oleh faktor lingkungan sekolah yang mengenalkan pembelajaran calistung sejak usia dini. Angka urutan atau ordinal memiliki pengaruh besar dalam menghitung angka kuantitas, karena dengan menalar urutan angka dengan baik dan benar maka dapat menentukan jumlah subjek dalam satu koleksi. Pada perhitungan jumlah subjek dalam satu koleksi, angka atau nomor yang disebutkan pada akhir subjek memiliki status khusus yaitu menentukan jumlah subjek dalam satu koleksi. Jean Piaget juga menjadikan angka urutan atau ordinal sebagai logika yang mendasari dan diperlukan anak tentang jumlah sebelum menghitung makna yang disebut dengan sequencing, yaitu anak-anak harus benar menghasilkan jumlah kata (verbal counting) dalam urutan dan menghitung urutan benda mereka sehingga mereka menghitung setiap subjek dengan tepat.

Tabel 2 Kemampuan Sub Aspek Angka Ordinal 


\begin{tabular}{llcc}
\hline \multicolumn{3}{c}{ Anak } \\
\hline $\begin{array}{l}\text { Mencocokkan } \\
\text { antara dua } \\
\text { koleksi dengan } \\
\text { item yang } \\
\text { berbeda warna. }\end{array}$ & 17 & $100 \%$ \\
\hline 2. & $\begin{array}{l}\text { Mengidentifikasi } \\
\text { tentang "lebih } \\
\text { dari". }\end{array}$ & 10 & $58,82 \%$ \\
3. & $\begin{array}{l}\text { Mengidentifikasi } \\
\text { tentang "kurang } \\
\text { dari" }\end{array}$ & 7 & $41,7 \%$ \\
\hline & $\begin{array}{l}\text { Mengidentifikasi } \\
\text { tentang } \\
\text { "ter/paling" } \\
\text { (subtizing) }\end{array}$ & 14 & $82,35 \%$ \\
\hline \multicolumn{1}{c}{ Jumlah } & $\mathbf{4 7}$ & $\mathbf{6 9 , 1 1 \%}$ \\
\hline
\end{tabular}

Menurut Thompson (2008) mengemukakan bahwa anak usia dini belajar mengatakan urutan nomor (angka kardinal) berawal dari meniru rangkaian kata-kata yang kemudian belajar konteks yang tepat untuk menghitung dengan berkoordinasi menunjuk benda dan kata angka.

Grath (2010) mengungkapkan bahwa setiap anak memiliki tahapan kemampuan yang berbeda-beda dalam mengenal angka ordinal dan kardinal, maka dari itu sangat penting bagi guru untuk memahami tingkat perkembangannya sehingga guru dapat dengan mudah memberikan stimulus untuk menambah pengetahuan anak-anak tentang angka.

\subsection{Kemampuan Aspek Geometri}

Geometriberadasangatdekatdengandun iaanak.Anakdapatmengenalikonsepgeometr imelaluigambarmaupunbenda-

bendadisekitarnyasepertipiring, bantal, gelasdansebagainya.MenurutSeefeltdanGal per (2010) mengungkapkanbahwa, " the more children work with geometric concepts, the more they can learn to explore spatial relations and experience mathematics"

yang berartibahwasemakinbanyakanakbelajartent anggeometri,

makamerekasemakindapatbelajaruntukmen geksplorasihubunganspasialdanpengalaman matematika.

Kemampuan mengenal geometri 2 dimensi anak usia 5-6 tahun di Kober AlHidayah Kecamatan Cikoneng Kabupaten Ciamis memiliki persentase sebanyak 70,58\% dari total seluruh anak. Hal tersebut dipengaruhi oleh pembelajaran yang mengenalkan bentuk-bentuk geometri 2 dimensi dari usia 4 tahun. Dua dimensi merupakan suatu benda yang memiliki sisi panjang dan lebar, sehingga tidak mempunyai ruang karena tidak mempunyai unsur ketebalan. Ciri-ciri 2 dimensi tersebut biasanya terdapat pada karya seni rupa, oleh karena itu pada proses pemberian tes aspek geometri 2 dimensi anak diberikan lembar kerja tentang identifikasi gambar-gambar geometri dalam bentuk 2 dimensi.

Tabel 3 Kemampuan Sub Aspek Geometri 2 Dimensi

\begin{tabular}{llcc}
\hline No. & \multicolumn{1}{c}{$\begin{array}{c}\text { Geometri 2 } \\
\text { Dimensi }\end{array}$} & $\begin{array}{c}\text { Jumlah } \\
\text { Anak }\end{array}$ & Persentase \\
\hline $\begin{array}{l}\text { Mengidentifikasi } \\
\text { bentuk } \\
\text { lingkaran. }\end{array}$ & 16 & $94,11 \%$ \\
\hline 2. & $\begin{array}{l}\text { Mengidentifikasi } \\
\text { bentuk persegi. }\end{array}$ & 12 & $70,58 \%$ \\
\hline 3. $\begin{array}{l}\text { Mengidentifikasi } \\
\text { bentuk segitiga }\end{array}$ & 12 & $70,58 \%$ \\
\hline & $\begin{array}{l}\text { Mengidentifikasi } \\
\text { bentuk persegi } \\
\text { panjang. }\end{array}$ & 9 & $52,94 \%$ \\
\hline & Jumlah & $\mathbf{4 8}$ & $\mathbf{7 0 , 5 8 \%}$ \\
\hline
\end{tabular}

Pada kemampuan geometri 3 dimensi memiliki persentase sebanyak $57,35 \%$ dari total seluruh anak, dan merupakan salah satu indikator dari kemampuan matematika dengan persentase hasil tes paling rendah. Menurut hasil dari observasi peneliti, hal ini disebabkan oleh belum tersedianya sentra balok atau metode permainan konstruksi pada setiap pembelajaran. Media balok 
konstruksi hanya disediakan untuk anakanak bermain pada saat jam istirahat saja, sehingga alokasi waktu anak untuk bermain konstruksi sangat tidak cukup. Menurut National Association for the Education of Young Children atau NAEYC (2002) bahwa salah satu kunci guru dalam mengembangkan kemampuan matematika anak usia 3-6 tahun adalah menyediakan cukup waktu, bahan dan dukungan bagi anak-anak untuk terlibat dalam bermain dan konteks dimana mereka mengeksplorasi dan memanipulasi ide-ide matematika dengan minat.

Tabel 4 Kemampuan Sub Aspek Geometri 3 Dimensi

\begin{tabular}{|c|c|c|c|}
\hline No & $\begin{array}{c}\text { Geometri } 3 \\
\text { Dimensi }\end{array}$ & $\begin{array}{c}\text { Jumla } \\
\text { h } \\
\text { Anak }\end{array}$ & $\begin{array}{c}\text { Persenta } \\
\text { se }\end{array}$ \\
\hline 1. & $\begin{array}{l}\text { Membuat } \\
\text { garis/menghubungk } \\
\text { an bagian samping } \\
\text { untuk membuat } \\
\text { baris balok. }\end{array}$ & 16 & $94,11 \%$ \\
\hline 2. & $\begin{array}{lr}\text { Membuat } & \text { vertikal } \\
\text { dan horizontal, tapi } \\
\text { masih } & \text { terbatas } \\
\text { (lantai } & \text { dan } \\
\text { dinding). } & \\
\end{array}$ & 16 & $94,11 \%$ \\
\hline 3. & $\begin{array}{l}\text { Membangun } \\
\text { lengkungan sudut } \\
\text { dengan } \\
\text { penambahan } \\
\text { potongan } \\
\text { sederhana. }\end{array}$ & 6 & $35,29 \%$ \\
\hline 4. & $\begin{array}{l}\text { Membangun } \\
\text { sebuah 'kandang' } \\
\text { dengan dinding } \\
\text { (dua blok tinggi } \\
\text { dan lengkungan). }\end{array}$ & 2 & $11.76 \%$ \\
\hline & Jumlah & 39 & $57,35 \%$ \\
\hline
\end{tabular}

Dalam mengenalkan konsep 3-D pada Pendidikan Anak Usia Dini (PAUD) seringkali menggunakan permainan balok konstruksi, karena permainan tersebut telah lama menjadi permainan pokok yang berkualitas tinggi untuk mengembangkan aspek kognitif anak. Permainan balok konstruksi dapat mendukung pembelajaran tentang bentuk kemampuan komposisi bentuk dan membantu mengembangkan penalaran, dan dapat membantu anak untuk mengembangkan konsep matematika dasar dan keterampilan spasial. Permainan balok kontruksi merupakan salah satu permainan yang menarik bagi anak usia dini, karena selalu disediakan dalam warna dan bentuk yang beragam. Menurut Clements dan Sarama ( 2010) mengungkapkan bahwa, "very young children can learn rich concepts about shape, if provided with varied examples and non-examples, discussions about shapes and their characteristics, and interesting tasks" yang berarti bahwa mengajarkan konsep geometri pada anak usia dini harus dengan menggunakan hal yang menarik. Hal tersebut ditegaskan Monighan dan Nourot (dalam Sarama dan Clements, 2009, hlm. 317) bahwa dalam permainan konstuktif di usia 5-6 tahun anak-anak memanipulasi benda untuk menghasilkan sesuatu dan meningkatkan kemampuan matematika anak sebanyak $50 \%$.

\section{KESIMPULAN}

Berdasarkan hasil penelitian dan pembahasan, diperoleh kesimpulan bahwa kemampuan matematika anak usia 5-6 tahun di Kober Al-Hidayah Kecamatan Cikoneng Kabupaten Ciamis termasuk dalam kriteria berkembang sesuai harapan dengan persentase $74,26 \%$ dari total seluruh anak.

Kemampuan mengenal angka kardinal anak usia 5-6 tahun di Kober Al-Hidayah Kecamatan Cikoneng Kabupaten Ciamis memiliki persentase sebanyak $94,11 \%$ dari total seluruh anak, dan pada kemampuan mengenal angka ordinal memiliki persentase sebanyak $69,11 \%$ dari total seluruh anak.

Kemampuan mengenal geometri 2 dimensi anak usia 5-6 tahun di Kober Al- 
Hidayah Kecamatan Cikoneng Kabupaten Ciamis memiliki persentase sebanyak $70,58 \%$ dari total seluruh anak. Sedangkan pada kemampuan geometri 3 dimensi memiliki persentase sebanyak $57,35 \%$ dari total seluruh anak.

\section{SARAN}

Hasil penelitian ini diharapkan dapat menjadi acuan untuk pendidik dan lembaga pendidikan agar dapat memberikan stimulasi yang tepat sesuai perkembangan dan kebutuhan anak melalui kegiatan pembelajaran yang menarik dan sehingga dapat mengembangkan kemampuan matematika anak khususnya usia 5-6 tahun khususnya di Kober Al-Hidayah Kecamatan Cikoneng Kabupaten Ciamis.

Rekomendasi penulis untuk penelitian selanjutnya yaitu mengadakan penelitian lebih lanjut mengenai kemampuan matematika, baik pada jenis penelitian yang sama maupun pada jenis penelitian yang berbeda agar penelitian pada pokok bahasan ini menjadi lebih sempurna. Penelitian dapat dilakukan terhadap pengembangan teknik pembelajaran untuk meningkatkan kemampuan matematika anak. Dengan begitu penelitian "Kemampuan Matematika Anak" bisa menjadi salah satu referensi untuk penelitian tersebut.

\section{UCAPAN TERIMA KASIH}

Penulis mengucapkan terima kasih kepada keluarga besar Prodi S1 PGPAUD UPI Tasikmalaya dan seluruh pihak yang terlibat dalam penelitian dan penyusunan artikel ilmiah ini. Kepala Sekolah beserta pendidik di Kober Al-Hidayah Kecamatan Cikoneng Kabupaten Ciamis yang telah mendukung dan membimbing selama pelaksanaan penelitian.

\section{DAFTAR PUSTAKA}

Andrews, N.W. dkk. (2010). Engaging Children in Early Mathematical Experiences. California: CPIN.

Arikunto, S. (2013). Prosedur Penelitian.

Jakarta: Rineka Cipta.

Clements, H.D. \& Sarama. J. (2009). Learning and Teaching Early Math. London: Routledge.

Clements, H.D. \& Sarama. J. (2010). Building Blocks and Cognitive Building Blocks Playing to

Know the World Mathematically. American Journal of Play. Hlm. 313-337.

Clemson, D. \& Clemson, W. (1994). Mathematics in the Early Years. London and New York:

Routledge

Cross dkk.(2009).Mathematic Learning in

Early Childhood.Washington DC: The National

Academies Press

Direkrorat Jendral PAUD. (2011). Konsep

Matematika untuk Anak Usia Dini. Jakarta: Kemendiknas.

Direktorat Pendas dan Menengah. (2007). Permainan Berhitung Permulaan di Taman Kanak

kanak. Jakarta: Kemendiknas.

Fitria, Analisa. (2013). Mengenalkan dan Membelajarkan Matematika pada AnakUsia Dini.

Jurnal Studi Gender dan Anak. Vol. 1 No. 2. Hlm. 45-55.

Hoerr, T.R., Boggeman, Sally., \& Wallach, Christine.(2010). Celebrating Every Learner.United

States of America:PB Printing.

Maeroff, G.I. (2006). Building Blocks. New York: Palgrave.

McGrath, Caroline. (2010). Supporting Early Mathematical Development. New York: A David

Fulton Book

Misbahuddin \& Hasan. (2013). Analisis Data Penelitian dengan Statistika. Jakarta: Bumi

Aksara

Mulyana, E.H. \& Nur, L. (2015). Statistika

Deskriptif. Tasikmalaya: UPI Kampus Tasikmalaya 
NAEYC \& NCTM. (2002). Early Childhood Mathematics: Promoting GoodBeginnings. Early

Childhood Mathematics Journal. Hlm. 1-21.

Peraturan Menteri Pendidikan dan Kebudayaan Nomor 137 Tahun 2014 tentang Standar

Dini.

Nasional Pendidikan Anak Usia

Peraturan Menteri Pendidikan dan Kebudayaan Nomor 146 Tahun 2014 tentang Kurikulum

2013 Pendidikan Anak Usia Dini.

Pound, L. (2008). Thinking and Learning about Mathematics in the Early Years. New York:

Nursery World.

Rahmawati, C.W. (2015). Identifikasi Kecerdasan Interpersonal Anak Usia 4-5 Tahun di TK Gugus Sido Mukti Kecamatan Mantrijeron Kota Yogyakarta. (Skripsi). Fakultas Ilmu Pendidikan, Universitas Negeri Yogyakarta,Yogyakarta.

Rohmah, N. \& Waluyo, E. (2014). Arithmetic Dice Media as Counting Concept Introduction Media in Early Childhood Setting. Indonesian Journal ofEarly Childhood Education Studies Vol. 3 (2). Hlm. 127-133

Sriningsih, N. (2009). Pembelajaran Matematika Terpadu untuk Anak Usia Dini. Bandung:

Pustaka Sebelas.

Sugiyono. (2007a). Statistika Untuk

Penelitian. Bandung: Alfabeta

Sugiyono. (2014b). Metode Penelitian Pendidikan Pendekatan

Kuantitatif,Kualitatif dan R\&D.

Bandung: Alfabeta.

Sugiyono. (2015c). Cara Mudah Menyusun Skripsi, Tesis dan Disertasi. Bandung:Alfabeta

Sujiono, Y.E. (2009). Konsep Pendidikan Anak Usia Dini. Jakarta: Indeks.

Thompson, I.. (2008). Teaching and Learning Early Number. New York : Open University
Universitas Pendidikan Indonesia. (2015). Pedoman Penulisan Karya Tulis Ilmiah. Bandung:

Universitas Pendidikan Indonesia. 